\title{
PELAKSANAAN PENDAFTARAN TANAH SISTEMATIS LENGKAP DI DESA MENANGA, KECAMATAN RENDANG, KABUPATEN KARANGASEM
}

\author{
Nyoman Handytya Wiarsa Putra, Anak Agung Sagung Laksmi Dewi, Luh Putu Suryani \\ Fakultas Hukum Universitas Warmadewa, Denpasar-Bali, Indonesia \\ handywiarsaputra@gmail.com, laksmiidewi29@gmail.com, putusuryani099@gmail.com
}

\begin{abstract}
Abstrak
Pendaftaran tanah sistematik lengkap merupakan program yang diselenggarakan oleh pemerintah, khususnya Kementerian Agraria dan Tata Ruang atau Kepala Badan Pertanahan Nasional. Hal ini bertujuan meningkatkan jumlah pendaftaran tanah yang menerbitkan sertifikat di Indonesia. Hal ini sangat penting, sehingga diharapkan partisipasi seluruh masyarakat akan pentingnya sertifikat dan diharapkan Badan Pertanahan Nasional memberikan sosialisasi tentang pentingnya kepemilikan hak atas tanah. Penerapannya tertuang dalam Peraturan Menteri Agraria dan Tata Ruang atau Kepala Badan Pertanahan Nasional Republik Indonesia Nomor 6 Tahun 2018 tentang Pendaftaran Tanah Sistematis Lengkap. Penelitian ini bertujuan untuk mengkaji proses pelaksanaan pendaftaran tanah sistematik lengkap serta kendala-kendalanya dan mengkaji upaya-upaya pelaksanaan pendaftaran tanah sistematik lengkap di Desa Menanga Kecamatan Rendang Kabupaten Karangasem. Metode yang digunakan adalah penelitian hukum empiris. Sumber data yang digunakan adalah data hukum primer dan sekunder, kemudian dianalisis melalui teknik interpretasi dan kualitatif. Hasil penelitian menunjukkan bahwa pelaksanaan pendaftaran tanah sistematis lengkap di Desa Menanga Kecamatan Rendang Kabupaten Karangasem dilakukan untuk mencapai kepastian hukum kepemilikan hak atas tanah. Pelaksanaan program ini belum efektif dan belum dilaksanakan secara optimal karena rendahnya partisipasi dalam pengurusan sertifikat tanah.
\end{abstract}

Kata Kunci: Kepastian hukum, Pendaftaran Tanah Sistematis Lengkap, Perlindungan hukum

\begin{abstract}
Complete systematic land registration is a program organized by the government, specifically the "Ministry of Agrarian Affairs and Spatial Planning or Head of the National Land Agency". with the aim of increasing the number of land registrations issuing certificates in Indonesia. This is very important, so it is hoped that the participation of the whole community in the importance of certificates and it is hoped that the National Land Agency will provide socialization about the importance of ownership of land rights. Its application is contained in the Regulation of the Minister of Agrarian Affairs and Spatial Planning or the Head of the National Land Agency of the Republic of Indonesia Number 6 of 2018 concerning Complete Systematic Land Registration. This study aimed to examine the process of implementing a complete systematic land registration and its obstacles and to examine the efforts to implement a complete systematic land registration in the village of Menanga, Rendang District, Karangasem Regency. The method used was empirical legal research. Sources of data used were primary and secondary legal data, then analyzed through interpretation and qualitative techniques. The results showed that the Implementation of Complete Systematic Land Registration in Menanga Village, Rendang District, Karangasem Regency was carried out to achieve legal certainty of land rights ownership. The implementation of this program has not been effective and has not been implemented optimally due to the low participation in the management of land certificates.
\end{abstract}

Keywords: Legal certainty, Complete Systematic Land Registration, Legal protection

\section{PENDAHULUAN}

Tanah pada kehidupan manusia memiliki peranan yang sangat penting karena dapat dikatakan sumber kesejahteraan, kemakmuran, dan kehidupan. Tanah memiliki nilai ekonomis pada kelangsungan kehidupan manusia karena tanah mampu menghasilkan sumber daya alam bagi banyak orang, maka dari itu tanah dikatakan memiliki ikatan yang kuat dengan manusia. Hal tersebut diatur dalam Pasal 33 ayat (3) Undang-undang Dasar Negara Republik Indonesia Tahun 1945 yang menyatakan Bumi air dan kekayaan alam yang terkandung didalamnya dikuasai oleh negara dan dipergunakan untuk sebesar-besar kemakmuran rakyat (Saleh, 1983); (Mulyadi, 2019). 
Diperkuat lagi dengan adanya Undang-undang Nomor 5 Tahun 1960 yang mengatur tentang "Peraturan Dasar Pokok-pokok Agraria atau yang lebih dikenal dengan Undang-undang Pokok Agraria (UUPA)". Dengan salah satu tujuan umum UUPA yaitu meletakkan dasar-dasar untuk memberikan kepastian hukum mengenai hak-hak atas tanah bagi rakyat seluruhnya (Salman \& Susanto, 2007). Alasan pemerintah untuk mengeluarkan kebijakan Pendaftaran tanah dikarenakan pemerintah ingin merealisasikan tujuan pokok dari Undang-undang Pokok Agraria (UUPA) tersebut.

Pendaftaran Tanah ialah sebuah susunan aktivitas yang dilaksanakan Pemerintah secara terusmenerus, berkesinambungan, dan juga teratur yang mencakup pengumpulan data, pengolahan data, pembukuan dan penyajian serta pemeliharaan data fisik dan data yuridis, pada bentuk peta dan daftar tentang bidang tanah dan juga satuan tempat tinggal susun, termasuk juga pemberian surat tanda bukti haknya pada bidang tanah yang telah terdapat hak milik atas satuan rumah susun dan hak-hak eksklusif yang membebaninya. Pendaftaran tanah dapat dibedakan menjadi dua yaitu pendaftaran tanah secara sistematis, yaitu pendaftaran tanah yang dilaksanakan secara serentak dan pendaftaran tanah secara sporadik, yaitu pendaftaran tanah pada suatu wilayah tertentu, atau pendaftaran tanah secara individual dan masal (Novi et al., 2016).

Dalam Undang-undang Pokok Agraria pada Pasal 19 ayat (1) disebutkan bahwa Untuk menjamin kepastian hukum oleh pemerintah diadakan pendaftaran tanah di seluruh wilayah Republik Indonesia menurut ketentuan yang diatur dengan peraturan pemerintah. Uraian penjelasan dari aturan ini ditujukan pada pemerintah untuk mengadakan pendaftaran tanah di seluruh Indonesia. Para pemegang hak atas tanah tersebut mempunyai hak untuk mendaftarkan tanahnya untuk dapat mendapatkan "surat tanda bukti hak atas tanah yang berlaku" tersebut sebagai alat pembuktian yang kuat sebagai pemegang hak atas tanah (Effendy, 1993)

Pendaftaran tanah diatur pada pasal 3 Peraturan Pemerintah No. 24 Tahun 1997, yang menjelaskan tujuan dari pendaftaran tanah, yaitu: a) Untuk memberikan kepastian hukum dan perlindungan hukum kepada pemegang hak atas suatu bidang tanah, satuan rumah susuh dan hak-hak lain yang terdaftar agar dengan mudah dapat membuktikan dirinya sebagai pemegang hak yang bersangkutan; b) Untuk menyediakan informasi kepada pihak-pihak yang berkepentingan termasuk pemerintah agar dengan mudah dapat memperoleh data yang diperlukan dalam mengadakan perbuatan hukum mengenai bidang-bidang tanah dan satuan-satuan rumah susun yang sudah terdaftar c) Untuk terselenggaraanya tertib administrasi pertanahan.

Guna mewujudkan hasil yang diharapkan, maka Badan Pertanahan Nasional (BPN) pun mengenalkan program "Pendaftaran Tanah Sistematis Lengkap" yang merupakan kegiatan pemerintah secara yang dilakukan secara terus-menerus, berkesinambungan dan juga teratur. Pendaftaran Tanah Sistematis Lengkap meliputi pengumpulan, pengolahan, pembukuan, penyajian dan pemeliharaan data fisik dan yuridis berupa peta dan daftar yang berkaitan dengan bidang tanah dan satuan rumah susun, termasuk dengan tanda bukti hak bagi bidang tanah yang sudah ada hak nya, dan hak milik atas satuan rumah susun serta hak tertentu yang membebaninya.

Program Pendaftaran Tanah Sistem Lengkap yang telah digencarkan oleh Badan Pertanahan Nasional (BPN) diharapkan untuk dapat mendorong mobilitas dan juga kemajuan ekonomi bagi masyarakat-masyarakat yang kurang mampu. Karenanya, sertifikat masyarakat dapat menjadi benda berharga yang dapat digunakan sebagai jaminan bagi bank dan juga lembaga keuangan. Program Pendaftaran Tanah Sistematis Lengkap ini selain mampu untuk menggerakkan perekonomian masyarakat, diharapkan juga agar dapat meminimalisir konflik-konflik pertanahan yang sering ada selama ini. Sebab, program ini akan mencatat semua jenis bidang tanah dan memetakannya secara akurat. Uraian di atas menyebabkan penulis tertarik untuk melakukan penelitian berkaitan dengan pemberian alas bukti hak milik dalam hal ini sertifikat kepemilikantanah melalui Pendaftaran Tanah Sistematis Lengkap

Penelitian terdahulu juga pernah melakukan penelitian yang relevean dengan penelitian ini, seperti Estiani \& Prabandari, (2019) mengungkapkan bahwa pengurusan sertifikat kepemilikan tanah sesuai prosedur dan regulasi Perundang-undangan. Dalam proses pengurusan sertifikat kepemilikan tanah menjadi tugas dan tanggungjawab lembaga pemerintah yang berwenang untuk mengedukasi masyarakat dalam pengurusan sertifikat kepemilikan tanah, ditemukan kendala dari masyarakat rendahnya minat dalam pengurusan sertifikat adalah masih belum ada sosialisi tentang pemahaman secara mendalam guna sertifikat tanah tersebut (Urip, 2013); (Rahman, 2010). Dari beberapa temuan 
penelitian terdahulu, maka penelitian saat ini mengkaji ulang regulasipelaksanaan pendaftaran tanah sistematis lengkap di Desa Menanga, Kecamatan Rendang, Kabupaten Karangasem dan mengungkapkan hambatan dan upaya dalam pelaksanaan pendaftaran tanah sistematis lengkap di Desa Menanga, Kecamatan Rendang, Kabupaten Karangasem.

\section{METODE PENELITIAN}

Jenis penelitian yang digunakan dalam penelitian ini yaitu penelitian empiris. Penelitian empiris di bidang hukum adalah penelitian yang memakai data primer sebagai data utamanya, dimana peneliti harus terjun langsung ke lokasi dengan Teknik pengumpulan data yaitu penelitian lapangan (field research) dan penelitian kepustakaan (library research) dengan mengumpulkan sejumlah data dari buku-buku dan ilmiah serta peraturan perundang-undangan maupun dokumen lainnya. Penelitian ini dilakukan di Kantor Badan Pertanahan Kabupaten Karangasem, karena peneliti ingin mengetahui apakah pensertifikatan tanah melalui pendaftaran tanah sistematis lengkap di Kantor Badan Pertanahan Kabupaten Karangasem berjalan berjalan dengan efektif atau tidak. Dengan menganalisis menggunakan teknik interpretasi dan kualitatif (Sunggono, 2003). Sedangkan bahan hukum yaitu bahan hukum primer dan sekunder yang selanjutnya dianalisis dengan menginterpretasikannya dan menyajikannya secara deskriptif yaitu metode menganalisis bahan hukum dengan menyusunnya secara sistematis dan menarik kesimpulan ilmiah.

\section{HASIL DAN PEMBAHASAN}

\section{Pelaksanaan Pendaftaran Tanah Sistematis Lengkap di Desa Menanga, Kecamatan Rendang, Kabupaten Karangasem}

Pasal 2 ayat (2) Peraturan Menteri Agraria dan Tata Ruang atau Kepala Badan Pertanahan Nasional Nomor 12 Tahun 2017 tentang Percepatan Pendaftaran Tanah Sistematis Lengkap, mengatur tujuan dari Pendaftaran tanah sistematis lengkap, yaitu Tujuan program PTSL adalah untuk percepatan pemberian kepastian hukum dan perlindungan hukum Hak atas Tanah masyarakat secara pasti, sederhana, cepat, lancar, aman, adil, merata dan terbuka serta akuntabel, sehingga dapat meningkatkan kesejahteraan dan kemakmuran msyarakat dan ekonomi negara, serta mengurangi dan mencegah sengketa dan konflik pertanahan".

Objek PTSL dapat kita temukan dalam Pasal 4 Peraturan Menteri Agraria dan Tata Ruang/Kepala Badan Pertanahan Nasional Nomor 6 Tahun 2018 tentang Pendaftaran Tanah Sistematis Lengkap. Objek PTSL meliputi seluruh bidang tanah, baik bidang tanah yang belum ada hak atas tanahnya maupun bidang tanah yang memiliki hak dalam rangka memperbaiki kualitas data pendaftaran tanah.

Berdasarkan hasil wawancara dengan Bapak Nyoman Suradnya selaku Ketua Satgas Fisik pada tanggal 1 Maret 2021 dikantor Pertanahan Kabupaten Karangasem diketahui bahwa secara garis besar tahapan pelaksanaan pendaftaran tanah sistematis lengkap yang dilakukan di Desa Menanga, Kecamatan Rendang dibagi menjadi beberapa tahapan:

1. Perencanaan dan Persiapan Pendaftaran Tanah Sistematis Lengkap dilaksanakan oleh Kepala Kantor Pertanahan Kabupaten Karangasem dengan menetapkan penyebaran target Pendaftaran Tanah Sistematis Lengkap di seluruh Kecamatan yang ada di Kabupaten Karangasem dan salah satunya di Desa Menanga, Kecamatan Rendang, Kabupaten Karangasem.

2. Penetapan Lokasi Kegiatan Pendaftaran Tanah Sistematis Lengkap Tahapan penetapan lokasi kegiatan Pendaftaran Tanah Sistematis Lengkap dilaksanakan oleh Kepala Kantor Pertanahan dengan menetapkan lokasi kegiatan Pendaftaran Tanah Sistematis Lengkap di wilayah kerjanya. Penetapan Lokasi tersebut dilakukan dalam satu wilayah kelurahan atau secara bertahap bagian demi bagian dalam satu hamparan.

3. Pembentukan dan Penetapan Panitia Ajudikasi Pendaftaran Tanah Sistematis Lengkap dilaksanakan dan dibentuk oleh Kepala Kantor Pertanahan. Susunan Panitia Ajudikasi Pendaftaran Tanah Sistematis Lengkap adalah sebagai berikut:

a. Ketua Panitia merangkap anggota yang dijabat oleh seorang pegawai Kantor Pertanahan.

b. Wakil Ketua yang membidangi infrastruktur agraria merangkap anggota yang dijabat oleh seorang pegawai Kantor Pertanahan yang memahami urusan infrastruktur pertanahan. 
c. Wakil Ketua yang membidangi hubungan hukum agraria merangkap anggota yang dijabat oleh seorang pegawai Kantor Pertanahan yang memahami urusan hubungan hukum pertanahan.

d. Sekretaris yang dijabat oleh seorang pegawai Kantor Pertanahan.

e. Kepala Desa/Kelurahan setempat.

f. Anggota dari unsur Kantor Pertanahan sesuai kebutuhan. Dengan mempertimbangkan ketersediaan sumber daya aparat pelaksana, setiap Panitia Ajudikasi Pendaftaran Tanah Sistematis Lengkap dapat dibentuk untuk lebih dari satu atau untuk beberapa wilayah kecamatan dengan melibatkan unsur perangkat setiap desa atau kelurahan yang bersangkutan.

Panitia Ajudikasi Panitia Ajudikasi Pendaftaran Tanah Sistematis Lengkap tersebut mempunyai tugas sebagai berikut (Martati \& Karjoko, 2017).

a. Menyiapkan rencana kerja Pendaftaran Tanah Sistematis Lengkap.

b. Mengumpulkan dokumen data fisik dan dokumen asli data yuridis untuk semua bidang di area yang bersangkutan dan berikan tanda terima dokumen tersebut kepada pemilik hak atau kuasanya.

c. Memberikan bantuan dalam melengkapi persyaratan bukti kepemilikan tanah sesuai dengan undang-undang.

d. Memeriksa kebenaran formal Data Fisik dan data Yuridis alat bukti kepemilikan atau penguasaan tanah.

e. Mengumumkan Data Fisik dan Data Yuridis bidang tanah yang sudah dikumpulkan.

f. Memfasilitasi penyelesaian sengketa antara pihak-pihak yang bersangkutan mengenai data yang diumumkan.

g. Mengesahkan hasil pengumuman sebagaimana dimaksud dalam huruf e yang akan digunakan sebagai dasar pembukuan hak atau pengusulan pemberian hak serta pendaftaran hak.

h. Menyampaikan laporan secara periodik dan menyerahkan hasil kegiatan kepada Kepala Kantor Pertanahan.

i. Melakukan supervisi pelaksanaan dan hasil pekerjaan Satuan Tugas Fisik dan Satuan Tugas Yuridis. Dalam melaksanakan tugas-tugas tersebut Panitia Ajudikasi Pendaftaran Tanah Sistematis Lengkap dibantu oleh Satuan Tugas Fisik (Satgas Fisik) dan Satuan Tugas Yuridis (Satgas Yuridis) yang dibentuk pada masing-masing kelurahan atau meliputi beberapa kelurahan.

4. Tahapan penyuluhan dilakukan oleh Kantor Pertanahan dan Panitia Ajudikasi Pendaftaran Tanah Sistematis Lengkap, Satgas Fisik dan Satgas Yuridis, dan dilakukan dengan memberikan penjelasan yaitu:

a. Manfaat bagi masyarakat, pemerintah dan negara atas hasil pelaksanaan program Pendaftaran Tanah Sistematis Lengkap.

b. Penetapan dan pemasangan tanda batas masing-masing bidang tanah.

c. dokumen yuridis yang perlu disiapkan."

d. Jadwal pengukuran bidang tanah dan pengumpulan data yuridis oleh Satgas Fisik dan Satgas Yuridis.

e. Hasil akhir kegiatan program Pendaftaran Tanah Sistematis Lengkap.

f. pembiayaan yang disediakan oleh Pemerintah atau sumber lain yang sah melalui kegiatan Pendaftaran Tanah Sistematis Lengkap.

g. Kemungkinan biaya atau pajak yang akan ditanggung oleh peserta kegiatan Pendaftaran Tanah Sistematis Lengkap.

5. Pengumpulan Data Fisik dan Data Yuridis Bidang Tanah, Tahapan pengumpulan data fisik dilakukan kegiatan pengukuran dan pemetaan yang meliputi pembuatan peta dasar pendaftaran, penetapan batas bidang-bidang tanah, pengukuran dan pemetaan bidang-bidang tanah dan pembuatan peta pendaftaran, pembuatan daftar tanah dan pembuatan surat ukur. Pembuatan peta dasar pendaftaran itulah yang merupakan dasar untuk pembuatan peta pendaftaran. Pada penerapan Pendaftaran tanah yang sistematis, digunakan peta dasar pendaftaran untuk memetakan bidangbidang tanah yang sudah didaftar. Sementara itu, dalam penerapan pendaftaran tanah secara sporadik, disediakan peta dasar pendaftaran supaya bidang tanah yang didaftar diketahui letaknya dalam hubungannya dengan bidang tanah lain di suatu wilayah, akhirnya dapat menghindari terjadinya penerbitan sertifikat ganda atas satu bidang tanah. Berikutnya yaitu tahapan 
pengumpulan data yuridis yang dilaksanakan untuk mendapatkan data mengenai hak dan siapa pemegang haknya serta ada atau tidaknya pihak lain yang membebaninya. Pengumpulan data tersebut menggunakan alat pembuktian berupa dokumen dan lain-lainnya. Dalam kegiatan pengumpulan data yuridis diadakan perbedaan antara pembuktian hak-hak baru dan hak lama.

6. Tahapan pemeriksaan tanah dilaksanakan untuk memastikan bahwa informasi yang terkandung dalam data fisik dan data yuridis memadai untuk kondisi lokasi.

7. Pengumuman data fisik dan data yuridis bidang tanah serta pembuktian hak, Tahapan pengumuman data fisik dan data yuridis bidang tanah serta pembuktian hak dilaksanakan untuk memenuhi asas publisitas dalam pembuktian pemilikan tanah maka dilaksanakan pengumuman data fisik dan data yuridis yang dipublikasikan di Kantor Pertanahan dan Kantor Kepala Desa atau Kelurahan setempat dan apabila ada di Kantor Pembantu (basecamp) Panitia Ajudikasi Pendaftaran Tanah Sistematis Lengkap, selama 14 (empat belas) hari kalender. Pembatasan waktu sepanjang 14 hari kalender adalah salah satu upaya mempercepat proses pendaftaran tanah, sehingga dengan adanya pembatasan waktu tersebut diharapkan proses pengumuman data fisik dan data yuridis akan lebih cepat, dan tahapan pendaftaran tanah melalui Pendaftaran Tanah Sistematis Lengkap dapat dilanjutkan pada tahap berikutnya. Asas publisitas sebagaimana dimaksud pada Ayat (1), diperkuat dengan memasang tanda atau papan yang bertuliskan: "Bidang Tanah atas Nama: Ini dalam proses pendaftaran tanah sistematis lengkap. bagi pihak yang berkeberatan agar menyampaikannya kepada panitia ajudikasi pendaftaran tanah sistematis lengkap Setempat", pada lokasi Pendaftaran Tanah Sistematis Lengkap oleh masing-masing pemilik tanah. Kebenaran materiil data fisik dan data yuridis sepenuhnya menjadi tanggung jawab pemohon/pemilik/peserta ajudikasi pendaftaran tanah sistematis lengkap.

8. Penerbitan keputusan pemberian hak atas tanah berdasarkan berita acara hasil pengumuman maka, ketua panitia ajudikasi pendaftaran tanah sistematis lengkap menetapkan keputusan penetapan hak atau keputusan penegasa atau pengakuan hak.

9. Pembukuan dan Penerbitan Sertipikat Hak atas Tanah.

Dalam upaya memberikan kepastian hukum untuk bidang pertanahan memerlukan ketersediaan perangkat hukum tertulis yang lengkap dan jelas serta dilakukan secara konsisten, maka dilaksanakannya Pendaftaran tanah melalui pendaftaran tanah sistematis lengkap. Ketersediaan perangkat hukum tertulis dapat menyebabkan siapapun yang mempunyai kepentingan akan mudah mengetahui kemungkinan apa saja yang tersedia untuk menguasai dan menggunakan keperluan tanah, bagaimana cara untuk memperolehnya, hak dan kewajiban, serta larangan dalam menguasai tanah dengan hak tertentu, saksi jika mengabaikan ketentuan, serta hal lain yang mempunyai hubungan dengan penguasaan dan penggunaan tanahnya (Harsono, 2007); (Ali Achmad Chomzah, 2004).

Kantor Pertanahan Kabupaten Karangasem pada tahun 2019 mendapatkan target PTSL sebanyak 30.000, 20.000 untuk target peta bidang tanah dan 10.000 untuk target Sertipikat Hak Atas Tanah. Ini merupakan Langkah pemerintah untuk mempercepat pendaftaran tanah yang belum bersertipikat di Kabupaten Karangasem. Khususnya di Desa Menanga, sertipikat yang telah di selesaikan dalam program ini sebanyak 1091 sertipikat.

\section{Hambatan Dan Upaya dalam Pelaksanaan Pendaftaran Tanah Sistematis Lengkap di Desa Menanga, Kecamatan Rendang, Kabupaten Karangasem}

Hukum ditegakkan dengan memperhatikan tiga unsur diantaranya kepastian hukum, kemanfaatan, dan keadilan. Karena tidak mudah menimbulkan keseimbangan antara ketiga unsur maka ketiga ketiga unsur itu tidak dapat di titik beratkan pada salah satu unsur saja. Secara normative, kepastian hukum adalah peraturan yang diciptakan dan diundangkan dengan pasti karena mengatur secara jelas dan logis (Suadi, 2016). Tanpa adanya kepastian hukum, seseorang tidak akan tahu apa yang harus dilakukan yang menyebabkan timbulnya perasaan yang tidak nyaman, dan ketika terlalu menitikberatkan kepada kepastian hukum dan terlalu mentaati suatu aturan alhasil akan kaku dan menimbulkan ketidakadilan.

Pendaftaran Tanah diadakan sebagai upaya menjamin kepastian hukum, pendaftaran tanah ini dilakukan untuk memenuhi kebutuhan masyarakat dan pemerintah (BPN, 1989). Agar dapat memberikan jaminan kepastian hukum dan legitimasi dari negara, maka setiap pemanfaatan dan penguasaan atas tanah yang termasuk dalam penanganan masalah harus didasarkan dan 
diselesaikan secara hukum (yuridis-teknis) serta tetap berlandaskan konstitusi yang diatur dalam konteks kemakmuran rakyat yang termasuk melaksanakan pendaftaran tanah di seluruh Indonesia dalam upaya memberikan jaminan kepastian hukum (Yamin \& Lubis, 2012).

Jaminan dan kepastian hukum pada hak atas tanah bagi seluruh rakyat Indonesia adalah salah satu tujuan utama dari UU Pokok Agraria yang harus dilaksanakan, maka pada Undangundang Pemerintah untuk menjalankan pendaftaran tanah di seluruh Indonesia yang bersifat rechtkadaster yang berarti memiliki tujuan untuk menjamin kepastian hukum dan kepastian hak.

Kepastian hukum adalah suatu hal yang menjadi harapan subjek hukum dalam memahami suatu aturan dilarang atau tidaknya oleh hukum, maka diperlukan suatu norma yang baik dan jelas dalam membentuk peraturan perundang-undangan yang memiliki penerapan jelas di masyarakat. Kepastian hukum bukanlah suatu hal yang mutlak untuk memenuhi tujuan hukum, namun dapat diartikan sebagai saran yang tepat sesuai dengan situasi dan kondisi yang memperhatikan asas manfaat dan efisiensi.

Pemerintah memberikan suatu jaminan kepastian dan perlindungan hukum kepada masyarakat dalam menguasai tanah dengan cara pendaftaran tanah. Penguasaan tanah memiliki arti fisik dan arti yuridis. Penguasaan tanah dalam arti yuridis adalah penguasaan tanah yang berlandaskan hak dan dilindungi oleh hukum serta memberikan kewenangan kepada pemegang hak tersebut untuk menguasai bidang fisik tanah yang dihaki, seperti pemilik tanah menggunakan atau mengambil manfaat dari tanah yang dihaki, tidak diserahkan kepada pihak yang lain. Pasal 1 angka 2 Peraturan Pemerintah Nomor 16 Tahun 2004 tentang Penatagunaan Tanah menyebutkan bahwa penguasaan tanah merupakan hubungan hukum antara orang perorangan, kelompok masyarakat atau badan hukum dengan tanah sesuai dengan UUPA. Berdasarkan uraian tersebut, diketahui bahwa adanya hak atas penguasaan tanah adalah serangkaian wewenang, kewajiban, dan atau larangan untuk berbuat atau tidak berbuat sesuatu bagi pemegang haknya.

\section{SIMPULAN DAN SARAN}

\section{Simpulan}

Berdasarkan analisis data, diketahui hasil penelitian mengungkapkan bahwa pelaksanaan pendaftaran tanah sistematis lengkap di Desa Menanga, Kecamatan Rendang Kabupaten Karangasem bertujuan untuk percepatan pemberian kepastian dan perlindungan hukum bagi pemegang hak atas tanah demi meningkatkan kesejahteraan rakyat. Namun dalam Pelaksanaanya program ini belum efektif dan belum terlaksana secara optimal yang dimana hanya sebanyak 1091 sertifikat yang baru terselesaikan. Adapun hamabatan yang dihadapi adalah Banyaknya syarat-syarat administrasi yang minim dimiliki oleh masyarakat yang akan dimasukkan dalam program Pendaftaran Tanah Sistematis Lengkap sehingga mempersulit pihak Badan Pertanahan Nasional untuk melengkapi berkas sebagai syarat pendaftaran tanah sistematik lengkap. Upaya yang dilakukan pihak Badan Pertanahan Nasional dengan cara melakukan sosialisasi berkelanjutan dan mempersiapkan dan mengarahkan syarat-syarat yang harus dilengkapi dalam pendaftaran tanah sistematik lengkap sehingga dengan adanya sosialisasi masyarakat lebih siap dalam melengkapi berkasberkas administrasi yang dibutuhkan pada program pendaftaran tanah sistematik lengkap.

\section{Saran}

Adapun saran-saran yang dapat diberikan terkait pengkajian yang telah dilakukan adalah diharapkan partisipasi semua masyarakat baik itu kesadaran akan pentingnya sertifikat dan pemerintah yang memfasilitasi dalam pendaftaran tanah pada program Pendaftaran Tanah Sistematis Lengkap yang saling bersinergi dalam mewujudkan reforma agraria yang baik. Diharapkan Badan Pertanahan Nasional mampu memberikan sosialisasi terhadap pentingnya kepemilikan hak atas tanah dengan bukti sertifikat yang didaftarkan di kantor pertanahan setempat, terutama melalui program-program yang tetap dan tepat sasaran.

\section{DAFTAR PUSTAKA}

Ali Achmad Chomzah. (2004). Hukum Agraria (Pertanahan Indonesia). Jakarta: Prestasi Pustaka. Effendy, B. (1993). Pendaftaran Tanah di Indonesia dan Pelaksanaannya. Bandung: Alumni Bandung. 
Estiani, \& Prabandari, A. P. (2019). Yuridis terhadap Penerbitan Sertifikat Hak atas Tanah Berdasarkan Akta Cacat Hukum. Juranal Notarius, 12(2), 811-823.

Harsono, B. (2007). Hukum Agraria Indonesia. Djmbatan.

Martati, A., \& Karjoko, L. (2017). Implementasi Asas Akuntabilitas dalam Pendaftaran Tanah Secara Sistematik. Universitas Surakarta.

Mulyadi, S. (2019). Penyelesaian Sengketa Kepemilikan Tanah Bersertifikat Ganda. Jurnal Yuridis, $6(1), 147-173$.

Novi, M., Njatrijani, R., \& Aminah. (2016). Tanggungjawab Penanggung terhadap Klaim Tertanggung dalam Pelaksanaan Asuransi Marine Hull and Machinery. Law and Justice, 5(2), $1-13$.

Rahman, T. (2010). Akibat Hukum Kebijakan Deregulasi Peningkatan Hak Atas Tanah Perumahan Terhadap Perjanjian Kpr yang Memuat Klausula Pembebanan Hak Tanggungan. Law Reform, 5(2), 1-46.

Saleh, R. (1983). Perbuatan Pidana dan Pertanggungjawaban Pidana. ksara Baru: Jakarta.

Salman, O., \& Susanto, A. F. (2007). "Teori Hukum (Mengingat, Mengmpulkan dan Membuka Kembali)." Bandung: Refika Utama.

Suadi, A. (2016). Politik Hukum: Perspektif Hukum Perdata dan Pidana Islam Serta Ekonomi Syariah. Jakarta: Kencana.

Sunggono, B. S. B. (2003). Metode Penelitian Hukum Jakarta. PT Raja Grafindo Persada.

Urip, S. (2013). Pendaftaran dan Peralihan Hak atas Tanah cetakan kelima PT Adhitya Andrebina Agung Jakarta. PT Adhitya Andrebina Agung.

Yamin, M., \& Lubis, A. R. (2012). Hukum Pendaftaran Tanah. Mandar Maju: Bandung. 